\title{
GENERAL MEDICAL ASPECTS OF MALIGNANT DISEASE
}

\author{
J. Q. Matthias, M.B., M.R.C.P. \\ Seniar Medical Registrar, St. Bartholomew's Hospital, London, E.C.I
}

THE physician's attitude to malignant disease has changed profoundly of recent years. Inoperable cancer, far from dictating defeatism, now presents a challenge. Increasingly effective chemical and physical methods of treatment, and an active diagnostic and therapeutic approach to complications and intercurrent disease, are resulting in the useful prolongation of life. The purpose of this paper is to discuss the general medical approach to the diagnosis and management of malignant disease and its metabolic and other complications. Some of the more recent advances are dealt with in some detail. The treatment of the growth itself is, however, considered elsewhere. It should perhaps be stated that the term 'malignant disease' is used in a general sense, referring to all cancers, including carcinomata, the reticuloses and leukæmia.

\section{General Management}

\section{The Management of the Patient}

The physician should adopt a sympathetic and unhurried attitude. A combination of kindliness, sincere interest and careful attention will almost invariably win the patient's confidence and simplify the general management. It is usually best to avoid revealing a fatal diagnosis to the patient. A sudden announcement will cause unnecessary distress and may, rarely, precipitate suicide. Only an occasional patient demands to know the truth, and even in reply to direct questioning an answer which does not shut out hope is invariably welcomed. It is certainly true to say that very few benefit from a knowledge of the outlook. The patient will usually gradually prepare himself for the inevitable. The truth is slowly realized and any attempt to soften the blow is well repaid by mutual confidence.

A further reason for the expression of a guarded opinion lies in the difficulty of assessing the prognosis accurately (Gordon-Taylor, 1959). Such an assessment is often a matter of conjecture, being limited by a paucity of information concerning the natural history of the disease. The inevitability of the disease is, at the best, never more than an estimate based on experience. However, an acceptable explanation of the situation must be offered so that the patient's anxiety may be allayed.

Any request for a second opinion should, if possible, be anticipated, so that the suggestion may come from the medical attendant.

Occasionally a genuine desire is expressed to know the diagnosis and prognosis as accurately as possible to enable business affairs to be ordered or a will to be drafted. Such information should be guarded. It is almost invariably better to acquaint a close relative with the outlook, so that affairs may be ordered circumspectly.

\section{The Management of the Relatives}

The close relatives must eventually be acquainted with the true situation. If time permits, it is usually kinder, initially, to proffer a guarded diagnosis and a hopeful prognosis. Later the truth may be gently revealed. The doctor can do a great deal to maintain the morale of the family by retaining a hopeful, considerate attitude. The wishes of the relatives concerning the general management of the patient should always be respected. It is most important to ensure that the family are quite satisfied that everything possible has been, and is being, done for the patient's welfare. Occasionally the relatives' wishes may have to be disregarded when the medical attendant is convinced that the patient's welfare lies in another direction. A word of explanation, however, is usually all that is needed to regain their full co-operation.

\section{Diagnostic Methods}

Accurate diagnosis is essential. Every effort should be made to arrive at a firm histological confirmation of the diagnosis, for, not uncommonly, the clinical features of other diseases may mimic those of malignant disease. This is particularly so of such diseases as lymphogranuloma venereum, granuloma inguinale, cat scratch fever and histoplasmosis, which may simulate malignant diseases of lymphoreticular tissue.

The importance of the early diagnosis of the malignant tumours which can be cured by sur- 
gical resection needs no emphasis. Evidence is accumulating that malignant diseases of similar cytological type may vary greatly in their rate of growth. Some grow slowly throughout the major part of their course, whilst others grow rapidly from their outset. Such a difference would account for the apparently contradictory observation that the longer symptoms are present before advice is sought the more favourable the outlook! This observation, of course, in no way detracts from the importance of making the diagnosis as early as possible in the course of the disease.

The distribution and extent of the disease should be assessed as accurately as possible to facilitate the formation of a logical therapeutic plan. It is important to be whole-hearted and consistent; half measures should be avoided. An accurate knowledge of the extent and distribution of the disease is also essential in forming an assessment of the prognosis and, in addition, may point to the development of a particular complication.

The approach to an apparently single metastasis is changing. Resection is now undertaken more frequently than hitherto. It is wise, however, to take every step to exclude occult metastases, particularly in the case of an apparently single cerebral deposit by bilateral carotid angiography and, where hepatic involvement is likely, by liver function tests and biopsy. Of particular value is the bromsulphthalein retention test, which will often detect multiple hepatic metastases when other liver function tests are normal. Should the serum alkaline phosphatase be somewhat elevated in the absence of obvious hepatic dysfunction, it will also assist in deciding whether the elevation is indeed due to hepatic dysfunction or to osteosclerotic metastases. It should be remembered, however, that hepatic excretion of bromsulphthalein is impaired in conditions which reduce the oxygen supply to the liver and also in the presence of fever.

\section{Advances in Diagnosis}

\section{Cytological Techniques}

(a) Exfoliative Cytology. The value of exfoliative cytology in the diagnosis of cancer is firmly established in carcinoma of the cervix, vagina, uterus and bronchus and also in the recognition of malignant involvement of the pericardium, pleuræ, peritoneum and meninges. With increasing experience, it seems possible that similar techniques will be of value in the diagnosis of malignant disease of the urinary system (particularly bladder) (Crabbe, Cresdee, Scott and Williams, 1956; Poole-Wilson, r959) and the stomach (Burnett, MacFarlane, Park and Kay, 1960; Forrest, 1960; Schade, 1958).

(b) Biopsy Techniques. Material obtained by the aspiration of tumours, organs or bone marrow may be smeared as a film or fixed, sectioned andoํำ stained by suitable methods. Interpretation, par ticularly of smears, often presents difficulties, but reliability will increase with experience. Possibly the smear or frozen section of aspirated materiak. will become more widely used as a rapid diagnostic: procedure. Theoretically, needle biopsy of an organ involved in a focal fashion (e.g. liver) maye yield negative results. However, a suspicious region can often be selected, so increasing the reliability $\frac{\infty}{\sigma}$

Flexible instruments which can be used undero direct vision are being developed for the biopsyes of gastric lesions. Some use a modified type of biopsy forceps (Benedict, I948; Kenamore, 1940) while others have a ' suction and guillotine' heade (Shiner, 1956; Tomenius, 1952).

Bone trephine is a valuable procedure whick will confirm marrow involvement by neoplastic tissue when aspiration biopsy fails. Myelofibrosis ${ }^{\omega}$ can be recognized and myelosclerosis differentiated with certainty from sclerosing metastases. This ${ }^{\circ}$ latter is particularly important if the primaryo tumour is not evident. The iliac crest presents $a_{0}$ convenient site when using a trephine of the Sacker ${ }^{\supset}$ Nordin type (Sacker and Nordin, 1954). The procedure is quick, relatively atraumatic and can be carried out under local anæsthesia.

Virtually any manipulation of a tumour (Code, $\vec{\circ}$ Parkard and Soutwick, 1954; Engell, 1959:Engell, 1959; Moore, Sandberg and Watne, 19(8) is theoretically associated with an increased risk dissemination, as shown by the demonstration (Long, Roberts, Magrath and McGrew, 1959) of related showers of cancer cells in the blood (Fisher and Turnbull, I955; Roberts, Watne $\stackrel{\circ}{\rightarrow}$ McGrath, McGrew and Cole, 1958; Roberts, Long, Jonasson, McGrath, McGrew and Cole 1960). The factors influencing the implantation of such tumour emboli are being actively investigated (Fisher and Fisher, 1959; Griffiths, 1960c Lucké, Breedis, Woo, Berwick and Nowell, $195^{2}$ Takahashi, 191 5; Lancet, 1960; Watanabe, 1954)? It seems likely that stress in the form of colds (Griffiths, I96ob), heat, trauma (Fisher and Fisher 1959), starvation (Griffiths and Hoppe, 1960a)? anæsthesia and operative interference (Buinauskas McDonald and Cole, 1958; Lewis and Cole, 1958). is important. Increased adrenal activity perhap in some way provides a common factor (Griffiths, I96ob and c).

\section{Cytochemical Techniques}

The demonstration of quantitative differences in intracellular enzymes and other chemical con stituents by histochemical staining and quantita tive biochemical techniques has been shown to bet of value.

A firmly established example is the alkaline 
phosphatase content of segmented neutrophils (Hayhoe, I960; Valentine, Beck, Follette, Mills and Lawrence, 1952; Valentine, 1960). The intensity of staining (Hayhoe, 1960; Wiltshaw and Moloney, 1955) or the actual amount of phosphorus liberated by an accurately determined number of cells can be estimated (Tanaka, Valentine and Fredricks, I960a; Valentine and Beck, I95I). In polycythæmia vera results two to six times normal are the rule, while in secondary polycythæmia normal results are obtained (Mitus, Mednicoff and Dameshek, 1959). Lesser elevations occur in the neutrocytosis of pyogenic infection (Kenny and Moloney, I957), myocardial infarction, trauma and diabetic acidosis, in leukæmoid reactions and following the administration of Vit. $B_{12}$, ACTH or corticosteroids. Presumably increased adrenocortical activity is the common denominator (Valentine, Follette, Hardin, Beck and Lawrence, 1954; Valentine, Follette, Solomon and Reynolds, 1957). Markedly low values are invariable in chronic myeloid leukæmia (Tanaka et al., 1960a) and occur at times in a variety of hæmatological and non-hæmatological disorders. Low levels occur consistently in paroxysmal nocturnal hæmoglobinuria (Beck and Valentine, 1957; Tanaka et al., r96oa; Tanaka, Valentine and Fredricks, I96ob) and hypophosphatasia (Kretchner, Stone and Bauer, 1958) and are not infrequent in idiopathic thrombocytopenic purpura, infectious mononucleosis (Tanaka et al., 1960a), myeloid metaplasia, myelofibrosis and sclerosis, pernicious anæmia in relapse, refractory anæmias (Dacie, Smith, White and Mollin, I959; Hayhoe and Quadlino, 1958; Mohler and Leavell, 1958), acquired hæmolytic anæmias, the hæmoglobinopathies, collagen diseases and Paget's disease of bone. Occasionally low values may be seen in terminal uræmia, chronic lead poisoning and atherosclerosis. The levels in chronic myeloid leukæmia may return to normal during a remission. No elevation, however, occurs following ACTH or corticosteroids.

In acute lymphoblastic leukæmia such segmented neutrophils as are present are rich in alkaline phosphatase, while those present in the myeloblastic variety are deficient.

Other forms of histochemical staining have also been employed in an effort to define the cytological varieties of acute leukæmia (Hayhoe, 1960). The periodic acid-Schiff technique (which stains carbohydrates, including glycogen) and peroxidase staining are examples. Lymphoblasts often stain by the PAS technique, but myeloblasts and promyelocytes are substantially negative. Conversely, the more mature myeloblasts and the promyelocytes contain peroxidases, whereas lymphoblasts are uniformly negative. Monoblastic and myelo- monoblastic varieties of acute leukæmia usually give intermediate results.

\section{Radiological Techniques}

The chest and skeleton can be explored effectively by the usual radiological techniques. The demonstration of intracranial and intra-abdominal tumours, however, often requires the application of refined techniques, including arteriography, venography, air encephalography and ventriculography. On occasion the induction of a pneumoperitoneum is justified to obtain accurate definition of the liver or spleen or of an intra-abdominal tumour.

The presence of retroperitoneal disease is frequently in doubt, for physical signs may be absent or unconvincing. Retroperitoneal pneumography (Rivas, 1947, 1950), where oxygen is insufflated through a needle inserted a little to one side of the midline and midway between the anus and coccyx, will often outline renal and adrenal tumours and enlarged retroperitoneal lymph nodes (Blackwood, r951; Davidson, Havard and Scott, 1959; Lerman, Harper, Hertzberg, Berman and Lerman, 1953). It is frequently combined with intravenous pyelography and abdominal venography (Helander and Lindbom, 1956).

\section{Radioisotope Techniques}

(a) Polycythæmia. Confirmation of the diagnosis may be obtained by the demonstration of the increased red cell mass by radioactive chromium (Szur, Lewis and Goolden, 1959) or phosphorus (Berlin, Lawrence and Gartland, r950) labelling.

(b) Hypersplenism. Excessive sequestration of red cells by the spleen may be detected by external counting over the organ following the labelling of red cells with radioactive chromium (Hughes Jones and Szur, 1957; Jandl, Greenberg, Yonemoto and Castle, 1956). In such an event, possibly, irradiation of the spleen or splenectomy may be suggested as a measure designed to prolong red cell life and to alleviate anæmia.

(c) The localization of primary and secondary tumours by the demonstration of a preferential uptake of radioactive phosphorus. This technique is most useful at craniotomy, when concentration of the isotope may be recognized by needle exploration of the brain substance using a suitable counter.

(d) A minority of carcinomata of the thyroid retain the ability to concentrate radioactive iodine. A further number can be induced to do so following total thyroidectomy or a course of antithyroid drugs. The technique is useful in assessing the practicability of radio-iodine therapy, in calculating the dose required and also for localizing secondary tumours. 


\section{Biochemical Techniques}

(a) Carcinoid Tumours. The urinary excretion of 5 -hydroxyindoleacetic acid is greatly elevated (to 50 to $600 \mathrm{mg}$. per day) in the presence of a carcinoid tumour. The qualitative test is simple to carry out, so that screening is practical. Quantities in excess of $15 \mathrm{mg}$. per day are sufficient to suggest the diagnosis. Normal values are in the range of 2 to $10 \mathrm{mg}$., so that it should be remembered that the ingestion of a few bananas may cause a false positive result (a banana contains about $4 \mathrm{mg}$. of serotonin).

(b) Chorioncarcinoma. Many patients with. embryonal tumours excrete increased amounts of chorionic gonadotrophin in the urine. It is not, however, a consistent finding even when involvement is widespread.

(c) Leucine Aminopeptidase. It has been suggested that increased levels of leucine aminopeptidase is a prominent finding in the urine in neoplastic disease and that elevations in the serum are particularly helpful in the diagnosis of carcinoma of the pancreas, especially in the absence of jaundice (Goldberg and Rutenberg, 1958; B.M.Y., 1958; Rutenberg, Goldberg and Pineda, 1958). However, elevated serum levels occur in pregnancy, acute pancreatitis, necrosis of the liver, chlorpromazine jaundice, liver metastases and extrahepatic biliary obstruction. Normal levels have also been observed in patients with carcinoma of the pancreas without jaundice (Harkness, Roper, Durant and Miller, I960; Hoffman, Nachlos, Gaby, Abrams and Seligman, I960; Miller and Worsley, 1960).

\section{Complications and Treatment}

I. Metabolic

(a) Hypercalcamia is a common accompaniment of neoplastic disease, complicating some 50 to $60 \%$ of cases of myeloma, $20 \%$ of patients with carcinoma of the breast and $10 \%$ with carcinoma of the bronchus. It has also been described in association with almost every variety of neoplasm. Usually widespread osteolytic bone metastases are present (Adair, Mellors, Farrow, Woodward, Escher and Urban, 1949; Clin.-Path. Conf., 1956; Lazlo, Schulman, Ballin, Gottesman and Schilling, 1952; Pearson, West, Hollander and Treves, 1954; Saunderson, I957), but occasionally hypercalcæmia may be the only overt manifestation of a malignant tumour (Thomas, Connor and Morgan, 1959). In such patients the marrow is usually diffusely infiltrated. However, hypercalcæmia has been recorded when no bone or marrow metastases have been discoverable at a carefully performed autopsy (Case records, 1953, 1957; Lucas, 1960; Plimpton and Gellhorn, 1956). Further, the hypercalcæmia has subsided following the surgical removal of the tumour (bronchus (Connor, Thomas and Howard, 1956), ڤ kidney, ovary (Plimpton and Gellhorn, 1956)), 3 only to recur later with the development of a non- $\square$ osseous metastasis.

The characteristic features of hypercalcæmia in- $\overrightarrow{\vec{c}}$ clude mental retardation and derangement (which may amount to a psychosis), skeletal myasthenia, $\frac{\mathrm{C}}{0}$ intestinal atony (resulting in anorexia, vomiting, constipation) and hyporeflexia. Associated hypo- $\bar{\varnothing}$ kalæmia and digitalis therapy increase the risk $\propto$ of cardiac arrest. Metastatic calcification, particu- $\omega$ larly causing renal impairment, is not uncommon, $\vec{O}$ but the development of paralimbal corneal cal- $\vec{A}$ cification (Cogan, Albright and Bartter, 1948), $\stackrel{\omega}{\sigma}$ common in chronic hypercalcæmia, is understand- $\frac{D}{0}$ ably rare. The onset of vomiting leads to the $\frac{0}{3}$. establishment of a vicious circle (dehydration, oliguria and increasing serum calcium levels) which may prove rapidly fatal.

The mechanisms involved in the production of the hypercalcæmia in the absence of bone meta- $O$ stases are obscure. It is possible that a tumour mayo produce a hyperparathyroid effect (Connor et al., 1956). Perhaps in some way proteolytic or depoly- $c$ merizing enzymes are stimulated, resulting in abnormal resorption of bone matrix. In the $\vec{\oplus}$ absence of renal failure serum phosphorus leve are commonly low, further simulating hyperpar. thyroidism. Thus, unless the cancer is readib recognizable, it may be difficult to exclude hypert parathyroidism. Marrow biopsy, together with the quantitative electrophoresis of serum proteins and estimation of the serum alkaline phosphatase, often $\stackrel{\mathbb{Q}}{\complement}$ clarifies the situation. Also it is claimed that $\overrightarrow{\vec{B}}$ corticosteroids will not reduce calcium levels in 3 hyperparathyroidism, but will do so, not uncommonly, in hypercalcæmia due to other causes? (Thomas et al., 1959).

Further mechanisms which may play a part include the administration of large amounts of $\dot{\sigma}$ calcium chloride by mouth to potentiate the action. of mercurial diuretics, increased intestinal absorp- 0 tion of calcium (cf. sarcoidosis and vitamin $D ₹$ intoxication), interference with the ability of the 의 skeleton to accept large amounts of calcium without $>$ persistent changes in the serum level and halisteresis (the dissolution of bone crystals without $\bar{N}$ concomitant or preceding resorption of associated matrix).

The treatment of hypercalcæmia complicating స్ల malignant disease may be approached in the following way:

(i) The withdrawal of therapeutic calcium salts.

(ii) The promotion of a diuresis. A 24 -hour $\stackrel{?}{+}$ urinary output of 2 to $4 \mathrm{l}$. is the aim. Usually intravenous fluids are required.

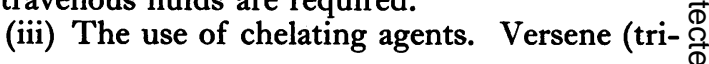


sodium ethylenediaminetetraacetic acid) is the agent of choice. Serum calcium levels are usually not reduced by commonly employed dosage schedules ( 2 to $6 \mathrm{~g}$. in each 24 hours), but ionized calcium is bound and increased amounts of calcium are excreted. Thus muscular effects are alleviated. From 250 to $1,000 \mathrm{mg}$. of versene are diluted in a suitable amount of fluid ( 100 to $\mathrm{I}, 000 \mathrm{ml}$.) and administered intravenously over a number of hours. In such dosage it is relatively non-toxic, but ' longterm ' therapy may produce renal damage, perhaps due to the effects of concomitant chelation of potassium, iron or manganese on the kidney or the deposition of increased amounts of calcium in the renal tubules (Dudley, Ritchie, Schilling and Baker, 1955; Foreman, Finnegan and Lushbaugh, 1956). If given rapidly intravenously the concentration of ionized calcium falls abruptly and death may occur due to cardiac arrest or hypocalcæmic convulsions.

(iv) The 'long-term' control of hypercalcæmia complicating malignant disease rests in the control of the disease by medical (Nathanson and Kelley, 1952) or surgical means.

(b) Renal Failure. Uræmia is a common terminal event in progressive malignant disease. Obvious prerenal, renal or postrenal causes may operate. The renal lesion of myelomatosis is of particular interest (Arends and Mandema, 1957; Osserman, 1959). Approximately one-third of patients show evidence of impaired renal function at diagnosis as judged by the blood urea. The presenting clinical picture is maybe that of uræmia with anæmia, but characteristically without hypertension and often without bone pain. Later in the course of the disease fully $75 \%$ of patients show impairment of renal function. The histological appearances (of dilated tubules containing proteinous casts) has suggested the possibility of tubular blockage, but it seems reasonable that the casts assume a coagulated form only after histological fixation. Whatever their physical state, however, the presence within the tubular epithelium cells of these abnormal proteins may grossly impair tubular function and lead to cellular atrophy and degeneration. Nephrocalcinosis is certainly a common, and may be a more important, cause of renal dysfunction in myelomatosis.

Uræmia due to nephrocalcinosis, with or without stone formation, is well documented in other malignant diseases associated with hypercalcæmia and hypercalciuria (Case records, 1953, 1957; Clin.-Path. Conf., 1956; Thomas et al., 1959). Amyloid deposition, the destruction of renal tissue by tumour and pyelonephritis are also important causes of renal dysfunction.

Hæmaturia, renal, ureteric and urethral pain, oliguria or anuria may be caused by the crystallization of uric acid in the renal tubules and urinary tract. Large amounts of uric acid result from the breakdown of neoplastic cells under the influence of cytotoxic agents (Krakoff, I960). In addition, 6-mercaptopurine (a purine analogue), by virtue of its site of action in nucleoprotein biosynthesis, results in the endogenous synthesis of greatly increased quantities of uric acid. It is, therefore, important to maintain an adequate urinary flow when using such agents.

(c) Cachexia. Weight loss is a common and often prominent feature of malignant disease. Appetite is impaired, food intake reduced and metabolism increased. However, these features are often insufficient to explain the rate and degree of weight loss. Probably other factors, such as impaired gastro-intestinal absorption or as yet unrecognized metabolic blocks, will prove to be important. It is claimed that anabolic steroids will sometimes arrest or reverse the weight loss, but convincing proof is lacking.

(d) Adrenal failure, due to the destruction of the adrenals by metastases, is a rare clinical event. More commonly it follows the abrupt cessation of long-term corticosteroid therapy or is precipitated, in patients receiving corticosteroids, by anæsthesia, surgery or infection.

(e) Amyloidosis. Primary amyloidosis (probably only seen in myelomatosis (Osserman, 1959)) is characterized by the deposition of an abnormal protein in the skin, subcutaneous tissues, muscles, tongue, gastro-intestinal tract (leading to malabsorption), heart and peripheral nerves. It is of interest that in this syndrome the number of plasma cells seen in marrow films is often considerably fewer than is usually the case in myelomatosis ( 20 to $35 \%$, as opposed to 60 to $95 \%$ ). This fact, perhaps, suggests a difference in ætiology. It may be legitimate to regard myelomatosis as a true 'primary' or ' malignant ' proliferation of plasma cells with a purposeless production of abnormal proteins and primary amyloidosis as a plasma cell response to an unknown antigen, which results in the production of abnormally large quantities of antibody.

Secondary amyloidosis, affecting in the main the liver, spleen, lymph nodes and kidneys, however, undoubtedly complicates many malignant diseases. It is probably true to say that at the present time, apart from rheumatoid arthritis, Hodgkin's disease is the commonest cause of secondary amyloidosis.

\section{Ancemia}

At some stage the majority of malignant diseases are complicated by the development of anæmia. Erythropoiesis may be inadequate subsequent to marrow infiltration by tumour tissue. In such case 
a film of the peripheral blood will often show leucoerythroblastosis. Chronic blood loss will eventually lead to the development of anæmia of the iron-deficiency type. Carcinoma of the stomach, or right side of the colon, commonly presents in this way. A megaloblastic anæmia due to deficiency of cyanocobalamin may also occur in patients with a diffuse gastric cancer. It is rare however, for even after total gastrectomy pernicious anæmia may not manifest itself for two to eight years.

Apart from occult or overt blood loss, red cell survival is commonly reduced. This is particularly important in the pathogenesis of anæmia of a severe degree (Matthias, 1959). The hæmolytic process is usually not associated with an autoimmune process and apparently responds to little apart from control of the malignant disease. A hæmolytic anæmia of auto-immune type is more rare. It is most commonly associated with malignant diseases of lymphoid tissue, but on occasions may occur in Hodgkin's disease and other cancers. Corticosteroid therapy of the auto-immune type of hæmolytic anæmia is probably more effective than such treatment of the non-immune type. Apart from any effect on the auto-immune process itself, the underlying malignant disease, being commonly of lymphoid tissue, is more often influenced favourably. Occasionally splenectomy is justified and may prolong red cell life by the removal of a major site of red cell sequestration and antibody formation. Benefit may also follow splenic irradiation or the administration of radioactive gold. The gold is absorbed on to carbon particles 30 to $50 \mu$ in diameter. When given intravenously the particles are preferentially taken up by the reticuloendothelial system and depress the ability of the system to synthesize antibodies.

Pancytopenia, a common sequel of bone marrow replacement in advanced cancer, may also result from the use of cytotoxic drugs and irradiation. Such iatrogenic depression of the bone marrow tends to be a temporary feature, recovery eventually occurring following withdrawal of therapy. When death does occur it is usually due to anæmia, infection or hæmorrhage. Blood transfusion, antibiotic therapy and corticosteroids will do much, but of greater effectiveness is the intravenous administration of hæmopoietic cells in the form of compatible marrow or fœetal liver (Ferrebee and Thomas, 1960; Mathé, r960).

A hæmorrhagic diathesis may also result from increased capillary fragility (rarely due to vitamin $\mathrm{C}$ or folic acid deficiency) and the presence of circulating macro- or cryoglobulins. Prothrombin deficiency, due to liver involvement or the failure to absorb vitamin $\mathrm{K}$, may aggravate a bleeding tendency.

Multiple transfusions are commonly compli- cated by the development of immune antibodies to sub-group antigens or to leucocytes. In malignant diseases of lymphoid tissue and plasma cells, where the immune response is depressed, the risk is probably less than in other conditions requiring repeated transfusion. All transfused blood should be cross-matched by the indirect Coombs' technique and ideally patients who will obviously require repeated transfusions should be paired with a polycythæmic or hæmochromatotic donor of compatible phenotype.

\section{Infection}

Patients with malignant disease are particularly prone to infection (Boggs and Frei, 1960). Cachexia, myasthenia, pulmonary aspiration, renal failure and urinary obstruction are important predisposing factors. Further causes include

(a) Immunological Incompetence. Cellular immunity may be impaired (Dubin, 1947; Grace and Kondo, 1958a; Schier, Roth, Ostroff and Schrift, 1956). Suppression of the tuberculin reaction is most marked in the reticuloses (Fairley 음 and Matthias, 1960; Hoyle, Dawson and Mather, 1954). Humoral immune mechanisms are also $\subseteq$ often incompetent (Evans, 1948; Howell, 1920; ๙ Larson and Tomlinson, 1953; Moreschi, 1914; $\vec{\odot}$ Silver, Utz, Fahey and Frei, 1960). Secondary antibody responses are usually affected to a greate degree than are responses of the primary type Such incompetence, most marked in malignant diseases of lymphoid tissue (Fairley, 1959; Shaw, Szwed, Boggs, Fahey, Frei, Morrison and Utz, 1960) and in myelomatosis (Lawson, Stuart, Paull, Phillips and Phillips, 1955; Zimmerman $\overline{\overline{0}}$ and Wendell, 1954), is often associated with a reduction in serum gamma globulins (Creyssel, Morel, Vieux, Pichat, Croizat and Revol, 1957; Creyssel, Morel, Pellet, Médard, Revol and $\frac{0}{3}$ Croizat, I958; Hudson and Wilson, 1960; Teitelbaum, Wiener and Desforges, 1959). Evidence is accumulating that, in such patients, resistance to infection may be increased by regular intramuscular injections of human gamma globulins.

(b) Neutropenia due to marrow infiltration, $\frac{\overrightarrow{ }}{0}$ depression or hypersplenism. The neutrophil response to infection is commonly suboptimal. مै

(c) Corticosteroid Therapy.

(d) Mechanical Factors. Impairment of respira- స్ట tory efficiency results in an increased susceptibility to respiratory infection. Thoracic deformity (due to vertebral collapse) and skeletal pain, in myelomat- $\frac{C}{\Phi}$ osis and bronchial obstruction in carcinoma of $\stackrel{\mathcal{C}}{+}$ the bronchus, may be quoted as examples.

Thrush occurs frequently in malignant disease. The infection may spread from the mouth to 
cause a painful œsophagitis and may rarely gain access to the blood stream via gastro-intestinal ulceration (Matthias and Rees, 1956). Dequalinium chloride lozenges and Nystatin are effective in oral and intestinal moniliasis, but intravenous Amphotericin B is required in the treatment of systemic Candida infections.

Bacterial septicæmia is common and is often due to infection by Staph. pyogenes or members of the coliform group. It is particularly likely to develop in patients with acute leukæmia, when it is usually associated with acute enteritis. Predisposing causes include the effects of cytotoxic drugs and antimetabolites on the gastro-intestinal mucous membranes.

Subacute meningitis caused by the yeast-like fungus Cryptococcus neoformans seems virtually confined to patients suffering from Hodgkin's disease and chronic malignant diseases of lymphoid tissue. It should be excluded in every such patient with meningism, associated with an increased cerebrospinal fluid protein, by an Indian ink preparation and culture on Sabouraud's medium. Cryptococcal meningitis often presents when the underlying disease is limited in extent or even when it is controlled. Recognition is important because Amphotericin B offers a considerable chance of cure. Such patients may also acquire other rare bacterial (e.g. Listerella monocytogenes) and fungal meningitides.

Herpes zoster is four times more common in the reticuloses than in the general population. In the great majority of cases the disease is active at the time of the infection and about one-third of infections follow irradiation or chemotherapy. Not infrequently the lesions occur in dermatomes related to irradiated areas. Generalization is often seen and occasionally myelitis or encephalitis supervenes.

\section{Neurological Complications}

Disturbances of function of the nervous system, at any level, and also of the muscles occur in association with malignant neoplastic disease in the absence of relevant secondary deposits (Brain and Henson, 1958). The tumour may be small enough to elude recognition except at autopsy. The picture is further complicated in that the neuromuscular disorder may present up to three years before the malignancy can be diagnosed (Heathfield and Williams, I954). There is no constant relationship between the size of the growth and the incidence or severity of the neurological complication or between the respective courses of the complication and the tumour. Recovery may occur even while the malignancy progresses. Surgical extirpation generally confers no beneficial effect.

The incidence of neurological complications in the absence of related deposits is not easy to discover. Lennox and Prichard (1950) record the incidence of peripheral neuritis in carcinoma of the bronchus as $1.7 \%$ of 299 patients. No such complication was observed in 300 patients with carcinomata elsewhere. Including all neurological disorders, it seems likely that the incidence is less than $5 \%$ in carcinoma of the lung (almost certainly the commonest cancer so complicated). Malignant tumours of the ovary, prostate, rectum and breast also may be associated with various neuromuscular disorders, but none has been reported in carcinoma of the csophagus. Williams, Diamond, Craven and Parsons (1959), reviewing 778 patients with lymphoma and leukæmia, record an overall incidence of peripheral neuritis of $0.1 \%$, most commonly occurring in myelomatosis (two patients). Demyelination, neuronal and axonal degeneration occur together with perivascular and meningeal collections of abnormal cells. The cerebrospinal fluid may show a raised protein and a paretic Lange curve, but rarely an increase in cells. Pyruvate tolerance is sometimes abnormal, but treatment with vitamin $B_{1}$ rarely improves matters.

Occasionally a vitamin $B_{12}$ deficiency complicates carcinoma of the stomach and the possibility of a causative metabolic disturbance, such as hypothyroidism, hypokalæmia or hypercalcæmia, should be kept in mind. Usually, however, the pathogenesis of the neurological disorder remains obscure. Current ætiological theories include the development of an allergic response, virus infection, unknown metabolic changes and the presence of a carcinotoxin. Treatment, except in rare instances, is limited and results are disappointing.

(a) Neuromuscular disorders, apart from the generalized muscular atrophy common in advancing cancer, are seen which cannot be explained by electrolyte changes, corticosteroid therapy or relevant metastases (Brain, I960). Carcinoma of the bronchus is most commonly so complicated. The proximal groups of muscles are usually affected most prominently by weakness and wasting, but the ocular and bulbar muscles may also be involved. Occasionally the weakness may be precipitated by muscular relaxants and sometimes a favourable response to neostigmine may be obtained. Occasionally the muscle disorder will be part of a dermatomyositis, long recognized as a complication of malignancy (Grace and Dao, r958b; Heathfield and Williams, .r960). Reflex activity is often retained and fasciculation is not a feature. The site of the lesion is unknown. Histological changes are usually non-specific, but occasionally sarcoid-like collections of cells are seen. The condition shows a tendency to spontaneous remission.

(b) A symmetrical peripheral neuropathy of 
mixed type is relatively common in carcinoma of the bronchus (Denny-Brown, 1948; Heathfield et al., 1954) and myelomatosis (I to $2 \%$ ) (Osserman, 1959; Victor, Banker and Adams, 1958; Williams et al., 1959). Primary amyloid infiltration of peripheral nerves accounts for at least some of the myeloma cases. The purely sensory type is more rare. Degeneration and loss of neurones in the anterior horns and posterior ganglia, together with the demyelination and degeneration of the axons of peripheral nerves and posterior columns, is often associated with severe and persistent pain and dysæsthesiæ of the extremities. Muscle tenderness may be elicited. Remissions may occur despite the progression of the malignancy.

(c) Central nervous system degenerations. Malignant disease is the commonest cause of corticocerebellar degeneration seen in hospital practice today (Brain et al., 1958). Often cerebellar dysfunction is associated with pyramidal tract and posterior column damage. There is a striking loss of Purkinje cells with axon degeneration, demyelination, perivascular cuffing and meningeal cellular infiltration. These forms are usually progressive, remissions being rare.

\section{Psychiatric Disorders}

Profound mental changes may result from severe electrolyte (uræmia, hypercalcæmia, hypokalæmia) and endocrine disturbances (hypothyroidism). However, psychiatric disorders may complicate malignant diseases in the absence of recognizable metabolic disturbances or intracranial neoplasms, whether of primary or secondary nature. It is being realised that a proportion of such patients suffer from widespread patchy cerebral demyelination. Possibly the mechanisms possess much in common with demyelination occurring in similar circumstances in the motor and sensory systems.

Disorders of mood, such as euphoria, anxiety, agitation or depression, are seen very commonly. As may occur in corticosteroid therapy, previously established mood characteristics are often accentuated. Hysteria is a well-recognized complication and not infrequently a frank psychosis may develop. Severe depression is accompanied by an increased risk of suicide.

Apart from the intellectual deterioration which accompanies severe illness, memory impairment may gradually become more prominent over a number of months. Exceptionally the onset may be acute and dementia may ultimately develop despite the control of the malignant disease. There is usually no tendency towards remission, but sympathetic psychotherapy, mood elevators, tranquillizers, antidepressants and electroconvulsant therapy are extremely helpful. Rarely prefrontal leucotomy may be indicated.

\section{The Terminal Phase}

Perhaps the greatest test of a physician's skill 气 lies in the care of the terminal or hopeless case. Distressing symptoms must be relieved whenever $\cong$ possible. Morale should be actively upheld and $\stackrel{C}{\complement}$ confidence fostered. Regular visits and a sym- $\overrightarrow{\vec{N}}$ pathetic approach are essential. A general atmo- $\overrightarrow{-}$ sphere of hopefulness should be maintained, defeat being rejected until absolutely unavoidable.

'O let him pass; he hates him that would upon the rack of this tough world stretch him out longer'.-King Lear, v, iii, 314.

There comes a time when active treatment is $\vec{\circ}$ unkind both to the patient and to the family. A $\overrightarrow{\vec{\omega}}$ time when the physician should no longer 'strive $\stackrel{\circ}{\circ}$ officiously to keep alive' (A. H. Clough, 'The $\mathbb{8}$ New Decalogue '). It is then his duty to ensure 3 that the patient does not suffer more than is absolutely unavoidable.

Asphyxial death is particularly frightening. $\infty$ Much can be done to avoid such a situation by the temporary control of an obstructive tumour or by irradiation, chemotherapy and diuretics. The $\frac{}{工}$ intracavity instillation of radioactive gold is often $\vec{c}$ effective in controlling effusions due to malignant involvement of serous membranes (Moses, Kent $\overparen{D}$ and Boatman, 1955). Paracentesis of the chest of $\vec{\bullet}$ abdomen should be undertaken when indicates? likewise colostomy for relief of obstruction in. carcinoma of the rectum or colon, or gastrostom in carcinoma of the œsophagus or cardia. Occasionally the surgical excision of a primary growth is justified even though multiple metastases may be present. The local excision of a fungating carcinoma of the breast is a good example. In addition, death from the effects of secondaries is usually less distressing than death from a primary tumour.

Local pain, particularly that originating in bone, may be relieved by irradiation, but on occasion the intrathecal injection of alcohol, neurectomy or chordotomy may be required. Some care should 3 be exercised to avoid the overfree use of addictive 8 analgesics too early in the course of the disease, lest distressing addiction, requiring huge and 0 frequent dosage, be promoted.

Opiates, however, eventually form the great $\frac{D}{3}$ standby. Once decided upon, it is better to administer a regular dose, unless the pain is clearly paroxysmal. Oral administration is practical. N Pulv. opii (120 mg.), tabs. morphine or liq. స్ morphine (1.8 ml. $\equiv I_{5} \mathrm{mg}$. morphine) are usually effective. If morphine is poorly tolerated, it is 0 worth trying papaveretum (20 mg.), hydromorphine $(2 \mathrm{mg}$.) or diamorphine $(5 \mathrm{mg}$.). Should the $\stackrel{f}{+}$ degree of hypnosis be undesirable, often pethidine $T$ (50 to $100 \mathrm{mg}$.), methadone (5 to 10 $\mathrm{mg}$.) or phenadoxone (10 mg.) will suffice. Phenazocine 
( 2 to $4 \mathrm{mg}$. parenterally) is an extremely useful drug for alleviating pain, possessing a very powerful analgesic action with little respiratory depression or hypnotic effect. The phenothiazines will ensure peace of mind and often control nausea and vomiting. Linctus opiatus or methadone $(4 \mathrm{ml}$. $\equiv 2 \mathrm{mg}$.) will relieve cough. It is most important to secure peaceful nights; to this end, in those accustomed, alcohol is useful, particularly if combined with an analgesic in the presence of pain. Fæcal obstruction should be avoided, the mouth kept clean and moist and attention paid to the pressure points, although dis- cretion should be shown in the final stages to avoid overburdening the patient.

\section{Summary}

Some aspects of a general medical approach to malignant disease and its complications have been considered. Probably the most striking change of recent years has been in the attitude of the physician towards inoperable cancer. A passive hopeless acceptance of the situation has been replaced by an active hopeful attitude, a change made possible by the development of increasingly effective diagnostic and therapeutic measures.

\section{REFERENCES}

Adair, F. E. Mellors, R. C. Farrow, J. H. Woodward, H. O. Escher, G. C., and Urban, J. A. (1949): The Use of Estrogens and Androgens in Advanced Mammary Cancer: Clinical and Laboratory Study of 105 Female Patients. F. Amer. med. Ass., 140, 1193.

Arends, A., and Mandema, E. (1957) : Observations on the Pathogenesis of the So-called Myelcma Kidney, Proc. sixth Cong. europ. Soc. Hamat., Basel. New York: S. Karger, 2, 137.

Blackwood, J. (195I): Presacral Perirenal Pneumography, Brit. F. Surg., 39, I I I.

BEck, W. S. and VALENTINe, W. N. (1957): Biochemical Studies on Leucocytes: II. Phosphatase Activity in Chronic Labelled Red Blood Cells, Amer. Y. Med., 9, 747.

BogGs, D. R., and FreI, E. (1960): Clinical Studies of Fever and Infection in Cancer, Cancer (Philad.), 13, 1240.

Brain, Sir Russell, and Henson, R. A. (1958): Neurological Syndromes Associated with Carcinoma: The Carcinomatous Neuromyopathies, Lancet, ii, 971 .

(1960): Discussion on the Acquired Myopathies, Proc. roy. Soc. Med., 53, 821 .

British Medical fournal (1958): Editorial, Leucine Aminopeptidase, ii, 15.

Buinauskas, P., McDonald, G. O., and Cole, W. H. (1958): Role of Operative Stress on the Resistance of the Experimental Animal to Innoculated Cancer Cells, Ann. Surg., 148, 642.

Burnett, W., MacFarlane, P. S., Park, S. D. C., and Kay, A. W. (1960): Carcinoma of the Stomach: An Evaluation of Diagnostic Methods Including Exfoliative Cytology, Brit. med. $\mathcal{F}$., i, 753.

Case Records of the Massachusetts General Hospital (Case No. 3906I) (1953): New Engl. f. Med., 248, 248.

(CASE No. 43161) (1957): Ibid., 256, 750.

Clinicopathological Conference (1956): A Case of Carcinoma of the Breast, Brit. med. F., i, r632.

Cogan, D., Albright, F., and Bartter, F. C. (1948): Hypercalcemia and Band Keratopathy: Report of 19 Cases, A.M.A. Arch. Ophthal., 40, 624.

Cole, W. H., Parkard, D., and Soutwick, H. W. (1954) : Carcinoma of the Colon with Special Reference to Prevention of Recurrence, f. Amer. med. Ass., 155, 1549.

Connor, T. B., Thomas, W. C., and Howard, J. E. (1956): Etiology of Hypercalcemia Associated with Lung Carcinoma, $\mathcal{F}$. clin. Invest., 35, 697.

Crabbe, J. G. S., Cresdee, W. C., Scott, T. S., and Williams, M. H. C. (1956): The Cytological Diagnosis of Bladder Tumours Amongst Dyestuff Workers, Brit. F. industr. Med., 13, 270.

Creyssel, R., Morel, P., Vieux, R., Pichat, A., Croizat, P., and Revol, L. (1957): L'éctrophorèse du. Serum au cours des Hémopathies Malignes, Sang, 28, 34 .

- Pellet, M., Médard, J., Revol, L., and Croizat, P. (1958) : Déficit en Gamma-globulines et Complications Infectieuses des Leucémies Lymphoides Chroniques, Ibid., 29, 383.

Dacie, J. V., Smith, M. D., White, J. C., and Mollin, D. L. (1959): Refractory Normoblastic Anæmia: Clinical and Hæmatological Study of Seven Cases, Brit. F. Hamat., 5, 56.

Davidson, J. K., Havard, C. W. H., and Scott, R. B. (I959): Radiological Demonstration of Enlarged Retroperitoneal Lymph Nodes, Lancet, i, 1008.

Denny-Brown, D. (1948): Sensory Neuropathy with Carcinoma, $\mathcal{F}$. Neurol. Neurosurg. Psychiat., II, 73.

Dubin, I. N. (1947): The Poverty of the Immunological Mechanism in Patients with Hodgkin's Disease, Ann. intern. Med., 27, 898 .

Dudley, H. R., Ritchie, A. C., Schilling, A., and Baker, W. H. (1955): Pathologic Changes Associated with the Use of Sodium Ethylenediaminetetraacetate in the Treatment of Hypercalcemia, New Engl. F. Med., 252, 33I.

Engell, H. C. (1955): Cancer Cells in the Circulating Blood: A Clinical Study on the Occurrence of Cancer Cells in the Peripheral Blood and in Venous Blood Draining the Tumour Area at Operation, Acta chir. scand., Supplement 20I, I.

- (1959): Cancer Cells in the Blood: A Five-to-Nine-Year Follow-up Study, Ann. Surg., 149, 457.

Evans, R. W. (1948): The Antibody Response in Cases of Radiation Lymphopenia and in the Reticuloses, F. Path. Bact., 60, 123 .

FaIRLeY, G. H. (1959): Hypogammaglobulinæmia in Chronic Lymphatic Leukæmia in Relation to Iso Agglutinins, Antibody Formation and Bacterial Infections, Proc. seventh Cong. europ. Soc. Hamat., London (85).

-, and Matrhias, J. Q. (1960): Cortisone and Skin Sensitivity to Tuberculin in Reticuloses, Brit. med. F., ii, 433.

Ferrebee, J. W., and Thomas, E. D. (1960): Transplantation of Marrow in Man, Ann. intern. Med., 106, 523. 
Fisher, B., and Fisher, E. R. (I959): Experimental Studies of Factors Influencing Hepatic Metastases: III, 'Effect of Surgical Trauma with Special Reference to Liver Injury, Ann. Surg., r50, 731.

Fisher, E. R., and Turnbull, R. B. (1955): The Cytological Demonstration and Significance of Tumour Cells in the Mesenteric Venous Blood in Patients with Colorectal Carcinoma, Surg. Gynec. Obstet., roo, 102.

- - and Fisher, B. (r959): Experimental Studies on Factors Influencing Hepatic Metastases: I, The Effect of Number of Tumour Cells Injected and Time of Growth, Cancer (Philad.), 12, 926.

Foreman, H., Finnegan, C., and Lushbaugh, C. C. (1956): Nephrotoxic Hazard from Uncontrolled Edathamil Calcium-disodium Therapy, $\mathcal{F}$. Amer. med. Ass., r6o, 1042.

Forrest, A. P. M. (1960): The Diagnosis of Gastric Cancer, Postgrad. med. J., 36, 775.

Goldberg, J. A., and Rutenberg, A. M. (1958): Colorimetric Determination of Leucine Aminopeptidase in Urine and Serum of Normal Subjects and Patients with Cancer and other Diseases, Cancer (Philad.), r1, 283.

Gordon TAYLOR, Sir G. (1959): The Incomputable Factor in Cancer Prognosis, Brit. med. $\mathcal{F}$., i, 455.

Grace, J. T., and Kondo, T. (1958a): Host Resistance in Cancer Patients, Ann. Surg., 148, 633.

-, and DAO, T. L. (1958b): Studies on the Relationship of Maligna nt Disease to Dermatomyositis, Clin. Res. Proc. 6, 302 .

Griffiths, J. D., and Hoppe, E. (I960a): Effect of Metabolic Stress on Development of Tumour Following Inoculation of Walker Carcinosarcoma Cells, Proc. Soc. exp. Biol. (N. Y.), 104, 467.

- (1960b): Increased "Take" of Walker 256 Tumor in Rats Following Hypothermia and Cold Stress, Surg., Forum, 10, 42.

- (1960c): The Dissemination of Cancer Cells During Operative Procedures, Ann. roy. Coll. Surg. Engl., 27, I4.

Harkness, J., Roper, B. W., Durant, J. A., and Miller, H. (1960): Serum Leucine Aminopeptidase Test: Appraisal of its Value in Diagnosis of Carcinoma of Pancreas, Brit. med. $\mathcal{F}$., i, 1787.

Haymoe, F. G., and Quaglino, D. (1958): Cytochemical Demonstration and Measurement of Leucocyte Alkaline Phosphatase Activity in Normal and Patholcgical States by Modified Azo Dye Coupling Technique, Brit. $\mathfrak{F}$. Hamat., 4, 375 .

_- (1960): 'Leukæmia: Research and Clinical Practice', p. 76. London: J. \& A. Churchill.

Heathrield, K. W. G., and Williams, J. R. B. (1954): Peripheral Neuropathy and Myopathy Associated with Bronchogenic Carcinoma, Brain, 77, 122.

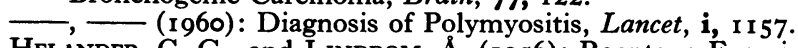

Helander, C. G., and Lindbom, $\AA$. (I956): Roentgen Examination of the Inferior Vena Cava in Retroperitoneal Expanding Processes, Acta radiol. (Stockh.), 45, 289.

Hoffman, E., Nachlos, M. M., Gaby, S. D., Abrams, S. J., and Seligman, A. M. (1960): Limitations in the Diagnostic Value of Serum Leucine Aminopeptidase, New Engl. F. Med., 263, 54I.

Howell, K. M. (1920): Failure of Antibody Formation in Leukemia, A.M.A. Arch. intern. Med., $26,706$.

Hoyle, C., Dawson, J., and Mather, G. (1954): Skin Sensitivity in Sarcoidosis, Lancet, ii, 164.

Hudson, R. P., and Wilson, S. J. (1960): Hypogammaglobulinemia and Chronic Lymphatic Leukemia, Cancer (Philad.), I3, 200.

Hughes Jones, N. C., and Szur, L. (1957): Determination of Sites of Red Cell Destruction Using ${ }^{51} \mathrm{Cr}$ Labelled Cells, Brit. F. Hamat., 3, 320.

Jandl, J. H., Greenberg, M. S., Yonemoto, R. H., and Castle, W. B. (1956) : Clinical Determination of the Sites of Red Cell Sequestration in Hemolytic Anemias, $\mathcal{F}$. clin. Invest., 35, 842.

Kenamore, B. (r940): A Biopsy Forceps for the Flexible Gastroscope, Amer. F. dig. Dis., 7, 539.

Kenny, J. J., and Moloney, W. C. (1957): Leucocyte Alkaline Phosphatase : Behaviour During Prolonged Incubation and Infection in Normal and Leukemic Leucocytes, Blood, 12, 295.

Krakoff, I. H. (1960): Mechanisms of Drug Action in Leukemia, Amer. F. Med., 28, 735.

Kretchmer, N., STONe, M., and BAuER, C. (1958): Hereditary Enzymatic Effects as Illustrated by Hypophosphatemia, Ann. N.Y. Acad. Sci., 75, 279.

Lancet (1960): Editorial, The Circulating Cancer Cell, ii, 476.

Larson, D. L., and Tomlinson, L. J. (r953): Quantitative Antibody Studies in Man: III, Antibody Response in Leukemia and other Malignant Lymphomata, $\mathfrak{F}$. clin. Invest., 32, 317.

Lawson, H. A., Stuart, C. A., Paull, A. M., Phillips, A. M., and Phillips, R. W. (r955): Observations on the Antibody Content of Blood in Patients with Multiple Myeloma, New Engl. Y. Med., 252, I3.

Lazlo, D., Schulman, C. A., Ballin, S., Gottesman, F. D., and Schilling, A. (1952): Mineral and Protein Metabolism in Osteolytic Metastases, 手. Amer. med. Ass., 148, 1027.

Lennox, B., and Prichard, S. (1950): The Association of Bronchial Carcinoma and Peripheral Neuritis, Quart. F. Med., 43, 97.

Lerman, F., Harper, J. G. M., Hertzberg, A. D., Berman, M. H., and Lerman, P. H. (1953): Presacral Oxygen Injection, $\boldsymbol{F}$. Urol. (Baltimore), 70, 312.

LEwIS, M. R., and Cole, W. H. (1958): Experimental Increase of Lung Metastases After Operative Trauma (Amputation of Limb with Tumor), A.M.A. Arch. Surg., 77, 621 .

Long, L., Roberts, S., McGrath, R., and McGrew, E. (r959): Simplified Technique for the Separation of Cancer Cells from Blood, $\boldsymbol{F}$. Amer. med. Ass., r70, 1785 .

Lucas, P. F. (1960): Acute Hypercalcæmia from Carcinomatosis Without Bone Metastases, Brit. med. F., i, r 330 .

LuCké, B., Breedis, C., Woo, Z. P., BerwiCk, L., and Nowell, P. (1952): Differential Growth of Metastatic Tumours in Liver and Lung: Experiments with Rabbit $\mathrm{V}_{2}$ Carcinoma, Cancer Res., 12, 734.

Matthias, J. Q., and Rees, E. G. (1956): Candida Septicæmia Complicating Antibiotic Therapy, F. Path. Bact., 7I, 512.

- (1959): Red Cell Life and Osmotic Fragility in the Anæmias of Hodgkin's Disease and Chronic Lymphatic Leukæmia, Proc. seventh Cong. europ. Soc. Hamat., London (40).

MAthé, G. (1960): Application of Hemopoietic Cell Grafts to the Treatment of Leukemia and Allied Diseases: A Critical Review, Blood, r6, ro73. 
Miller, M. B., and Worsley, L. (1960): Serum Leucine Aminopeptidase in Carcinoma of the Pancreas and other Diseases, Brit. med. F., ii, 1419.

Mitus, W. J., Mednicoff, I. B., and Dameshek, W. (1959): Alkaline Phosphatase of Mature Neutrophils in Various 'Polycythemias', New Engl. F. Med., 260, I 13 I.

Mohler, D. N., and Leavell, B. S. (1958): Aplastic Anemia: Analysis of 50 Cases, Ann. intern. Med., 49, 326.

Moore, G. E., Sandberg, A. A., and Watne, A. L. (r960): Spread of Cancer Cells and its Relationship to Chemotherapy, f. Amer. med. Ass., r72, 1729.

Moreschi, Von C. (r914): Ueber antigene und pyrogene Wirkung des Typhus bacillus bei Leukämischen Kranken, Z. Immun.-Forsch., 21, $4 \mathrm{IO}$.

Moses, C., Kent, E., and Boatman, J. B. (1955): Experimental and Clinical Studies with Radioactive Colloidal Gold in the Therapy of Serous Effusions Arising from Cancer, Cancer (Philad.), 8, 417.

Nathanson, I. T., and Kelley, R. M. (1952): Hormonal Treatment of Cancer, Ibid., $246,135$.

Osserman, E. F. (1959): Plasma Cell Myeloma, New Engl. F. Med., 26r, roo6.

Pearson, O. H., West, C. D., Hollander, V. P., and Treves, N. E. (1954): Evaluation of Endocrine Therapy for Advanced Breast Cancer, Y. Amer. med. Ass., r54, 234.

Plimpton, C. H., and Gellhorn, A. (1956): Hypercalcemia in Malignant Disease Without Evidence of Bone Destruction, Amer. F. Med., 21, 750 .

Poole-Wilson, D. S. (1959): Occupational Tumours of the Bladder, Proc. roy. Soc. Med., 53, 801.

Roberts, S., Watne, A., McGrath, R., McGrew, E., and Cole, W. H. (1958): Technique and Results of Isolation of Cancer Cells from Circulating Blood, A.M.A. Arch. Surg., 76, 334.

- Long, L., Jonasson, O., McGrath, R., McGrew, E., and Cole, W. H. (1960): The Isolation of Cancer Cells from the Blood Stream During Uterine Curettage, Surg. Gynec. Obstet., Ir1, 3.

Rivas, M. R. (1947): Nueva Tecnica de Diagnostico Radiografico Applicable a Organos y Estructuras Retroperitoneales: Mediastinicas y Cervicales, Rev. clin. esp., 25, 206.

(1950): Roentgenological Diagnosis :Generalised Subserous Emphysema Through a Single Puncture: Amer. $\mathcal{F}$. Roentgenol., 64, 723.

Rutenberg, M., Goldberg, J. A., and Pineda, E. P. (1958): Leucine Aminopeptidase Activity: Observations in Patients with Cancer of the Pancreas and other Diseases, New Engl. F. Med., 259, 469.

SACker, L. S., and Nordin, B. E. C. (1954): A Simple Bone Biopsy Needle, Lancet, i, 347.

SAunderson, P. H. (1957): Hypercalcæmia and Renal Failure in Multiple Secondary Carcinoma of Bone, Brit. med. 7 ., ii, 275 .

Schade, R. O. K. (1958): Exfoliative Cytology of Gastric Carcinoma, Ibid., i, 743.

Schier, W. W., Roth, A., Ostroff, G., and Schrift, M. H. (1956): Hodgkin's Disease and Immunity, Amer. F. Med., 20, 94 .

Shaw, R. K., Szwed, C., Boggs, D. R., Fahey, J. L., Frei, E., Morrison, E., and Utz, J. P. (ig6o): Infection and Immunity in Chronic Lymphocytic Leukemia, A.M.A. Arch. intern. Med., 106, 467.

Shiner, M. (1956): Gastric Biopsy Under Direct Visual Control with the Hermon Taylor Gastroscope, Lancet, ii, 178.,

Silver, R. T., Utz, J. P., FAHEY, J., and Frei, E. (1960): Antibody Response in Patients with Acute Leukemia, F. Lab. clin. Med., 56, 634 .

Szur, L., Lewis, S. M., and Goolden, A. W. G. (1959): Polycythæmia Vera and its Treatment with Radioactive Phosphorus, Quart. F. Med., 28, 397.

Takahashi, M. (1915): An Experimental Study of Metastases, F. Path. Bact., 20, I.

Tanaka, K. R., Valentine, W. N., and Fredricks, R. E. (I960a): Diseases or Clinical Conditions Associated with Low Leukocyte Alkaline Phosphatase, New Engl. F. Med., 262, 912.

- - (1960b): Studies on Leukocytic and Erythrocytic Enzymes in Paroxysmal Nocturnal Hemoglobinuria, Clin. Res. Proc., 8, 132.

Teitelbaum, J. I., Wiener, J., and Desforges, J. F. (I959): A Serologic and Electrophoretic Study of the Malignant and Proliferative Disorders of the Hemopoietic and Reticulo-endothelial Systems, F. Lab. clin. Med., 53, 535.

Thomas, W. C., Connor, T. B., and Morgan, H. G. (1959): Diagnostic Considerations in Hypercalcemia, New Engl. F. Med., 260, 591 .

Tomenius, J. (1952): A New Instrument for Gastric Biopsies Under Visual Control, Gastroenterology, 2r, 544.

Valentine, W. N., and Beck, W. S. (195I): Biochemical Studies on Leucocyte Phosphatase Activity in Health, Leucocytosis and Myelocytic Leukemia, f. Lab. clin. Med., 38, 39.

- - - Follette, J. H., Mills, H., and Lawrence, J. S. (r952): Biochemical Studies in Chronic Myelocytic Leukemia, Polycythemia Vera and Other Idiopathic Myeloproliferative Disorders, Blood, 7, 959.

, Follette, J. H., Hardin, E. B., Beck, W. S., and Lawrence, J. S. (1954): Studies on Leucocyte Alkaline Phosphatase Activity: Relation to Stress and Pituitary Adrenal Activity, f. Lab. clin. Med., 44, 2 r9.

- - , Solomon, D. H., and Reynolds, J. (1957): Relationship of Leucocyte Alkaline Phosphatase to Stress, to ACTH and to I 7 -hydroxycorticosteroids, Ibid., 49, 723.

- (1960): The Metabolism of the Leukemic Leucocyte, Amer. F. Med., 28, 699.

Victor, M., Banker, B. Q., and Adams, R. D. (1958): The Neuropathy of Multiple Myeloma, f. Neurol. Neurosurg. Psychiat., 21, 73.

Watanabe, S. (1954): The Metastasizability of Tumor Cells, Cancer (Philad.), 7, 2 I 5.

Williams, H. M., Diamond, H. D., Craver, L. F., and Parsons, H. (1959): 'Neurological Complications of Lymphomas and Leukemias'. Springfield, Illinois: Charles C. Thomas.

Wiltshaw, E., and Moloney, W. C. (I955): Histochemical and Biochemical Studies on Leucocyte Alkaline Phosphatase Activity, Blood, I0, I 120.

Zimmerman, H. H., and Wendell, H. H. (1954): Recurrent Pneumonia in Multiple Myeloma and Some Observations on Immunological Response, Ann. intern. Med., 41, 152. 